\title{
Obsidian Subsources Utilized at Sites in Southern Sardinia (Italy)
}

Robert H. Tykot ${ }^{1}$, Michael D. Glascock ${ }^{2}$, Robert J. Speakman ${ }^{3}$, and Enrico Atzeni ${ }^{4}$

${ }^{1}$ Anthropology, University of South Florida, 4202 E. Fowler Ave., SOC107, Tampa, FL, 33620

${ }^{2}$ Research Reactor Center, University of Missouri-Columbia, Columbia, MO, 65211

${ }^{3}$ Museum Conservation Institute, Smithsonian Institution, Suitland, MD, 20746

${ }^{4}$ Dipartimento di Scienze Archeologiche e Storico-Artistiche, Universita di Cagliari, Cagliari, Italy

\begin{abstract}
While geochemical analysis of obsidian artifacts is now widely applied around the world, both new instrumental methods and new research questions continue to be applied in archaeology. In the Mediterranean, many analytical methods have been employed and proven successful in distinguishing all of the island sources. In this study, results are presented from the virtually non-destructive, LA-ICP-MS multi-element analysis of 95 carefully selected obsidian artifacts from four neolithic period sites in southwestern Sardinia. The patterns of exploitation of specific Monte Arci obsidian subsources revealed in this study support a down-the-line model of obsidian trade during the neolithic period, but with chronological changes that are best explained by increased socioeconomic complexity.
\end{abstract}

\section{INTRODUCTION}

The existence of obsidian sources on Sardinia (Italy), and their usage by prehistoric cultures for a variety of stone tools, has been widely known at least since the 19th century when early geological and archaeological studies were conducted $[1,2]$. While it was generally thought that obsidian artifacts found in Sardinia would have actually come from the natural sources at Monte Arci, and not from one of the other central Mediterranean island sources, chemical analyses to fingerprint sources and match artifacts to them were not successful until the 1960s, and very little was done in Sardinia until the 1980s, when it became clear that there were multiple subsources on Monte Arci that could be chemically distinguished [3, 4]. Detailed survey and analysis of geological samples from Monte Arci have since then identified at least seven subsources of usable obsidian, and demonstrated that different chronological and geographic patterns of their usage made it necessary to assign artifacts to specific subsources and not just to Monte Arci [5-9]. Possible explanations for this include differences in the quantity and physical properties of obsidian from each subsource; the accessibility of the subsources and the modes of transport; and changes in the socioeconomic system involved in production and exchange [10]. Type SA obsidian exists in situ in a concentrated area near Conca Cannas on the southwestern slopes of Monte Arci, and is black-gray, fairly glassy, with a high level of transparency. Types SB1(a,b,c) and SB2 may be found in multiple outcrops on the western slopes, but in less concentrated quantities, and varies from transparent to opaque, sometimes with many phenocrysts. Type SC obsidian, which is black, opaque, and less glassy, is abundant in mainly secondary deposits on the east side of Monte Arci [7, 11, 12]. 
It is generally thought that earlier neolithic societies were egalitarian in nature, while specialization in labor activities and the emergence of social/economic ranking are thought to have emerged during the late neolithic period. This is examined here by establishing whether there was consistency or change over time in the use of obsidian subsources in Sardinia, as well as any geographic variation in their usage. Obsidian artifacts were selected from four archaeological sites in southern Sardinia (Figure 1) to complement the previous studies done on a significant number of sites and artifacts in northern Sardinia and in Corsica [6,11,13, 14]. Those studies suggested that there was a major chronological change, mainly with a shift from all three major Sardinia subsource groups (SA, SB, SC) being used during the Early Neolithic (ca. 57004700 BC), to negligible use of SB and greater use of SC by the Late Neolithic (ca. 4000-3200 $\mathrm{BC}$ ). This study tested whether or not the same patterns existed in southern Sardinia, and therefore the hypothesis that socioeconomic systems rather than subsource location/access were the main factors in obsidian artifact production and exchange.

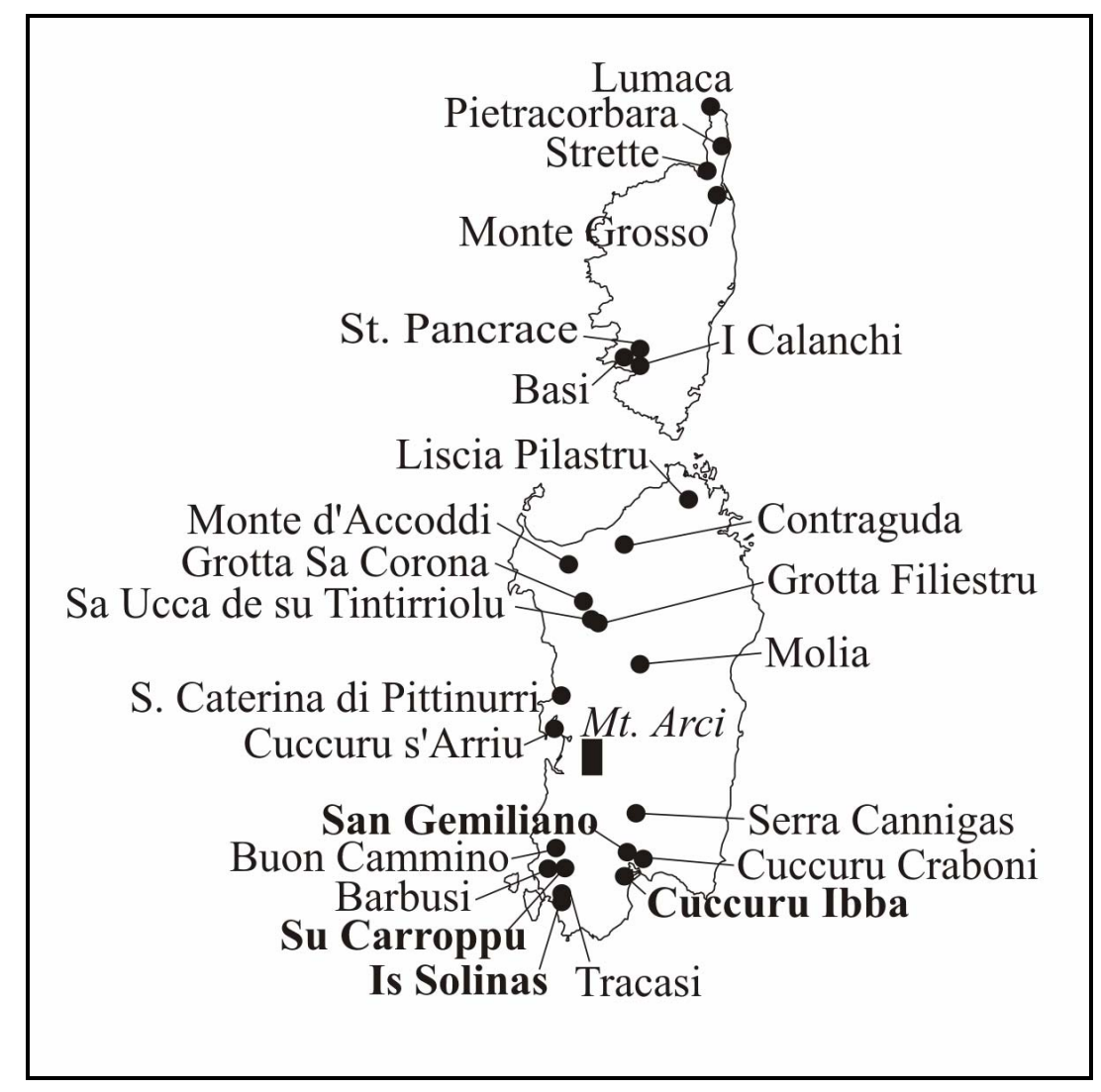

Figure 1. Neolithic sites in Sardinia and Corsica mentioned in this paper. Sites with obsidian tested in this study are in bold.

\section{ARCHAEOLOGICAL SAMPLES}

Archaeological samples were selected in 2002, from four neolithic sites in southern Sardinia, with the specific intention of expanding upon the limited data on obsidian source patterns in the region south of the Monte Arci sources. The only previous study, by J. Michels et 
al. [15], used atomic absorption spectroscopy to analyze a total of 53 artifacts from 5 neolithic period sites, all in the southwestern most part of Sardinia, in the Iglesias and Carbonia regions. The selection of 95 samples from these four sites would significantly expand the data available for comparing subsource patterns in different regions.

Su Carroppu (Sirri, Carbonia) is an Early Neolithic site located in southwestern Sardinia. In the form of a rock-shelter, excavations were done in the 1960s and 1970s by Enrico Atzeni, producing at least a few hundred obsidian artifacts [16-18]. A set of 15 obsidian samples were initially analyzed by Michels et al. [15], while another 20 artifacts were tested in this study (Figure 2a). A separate project, on 63 samples, was recently done by Lugliè et al. [19], using particle induced X-ray emission (PIXE).

Is Solinas (Giba) is a Late Neolithic open-air site located in the southwestern corner of Sardinia, very close to the Golfo di Palmas. A surface collection of obsidian, numbering in the thousands, and other lithic and ceramic materials were made by Atzeni [20]. A set of 24 samples were selected for analysis.

Cuccuru Ibba (Capoterra) is another Late Neolithic open-air site, located on the western side of the Stagno di Cagliari, not far from the Nuragic (Bronze Age) settlement of the same name, in an area now submerged. A large quantity of Ozieri (Late Neolithic) ceramic materials were collected on the surface by farmers, along with flint and obsidian tools, and marine shells [21-22]. Twenty-nine obsidian artifacts were selected for analysis.

San Gemiliano (Sestu) is a Late Neolithic village settlement located inland, due north of Cagliari. The extensive site consists of the remains of hut dwellings spread over several hectares, and large numbers of lithic and ceramic artifacts have been collected from surface deposits [23]. Twenty-two obsidian artifacts were selected for analysis (Figure 2b).
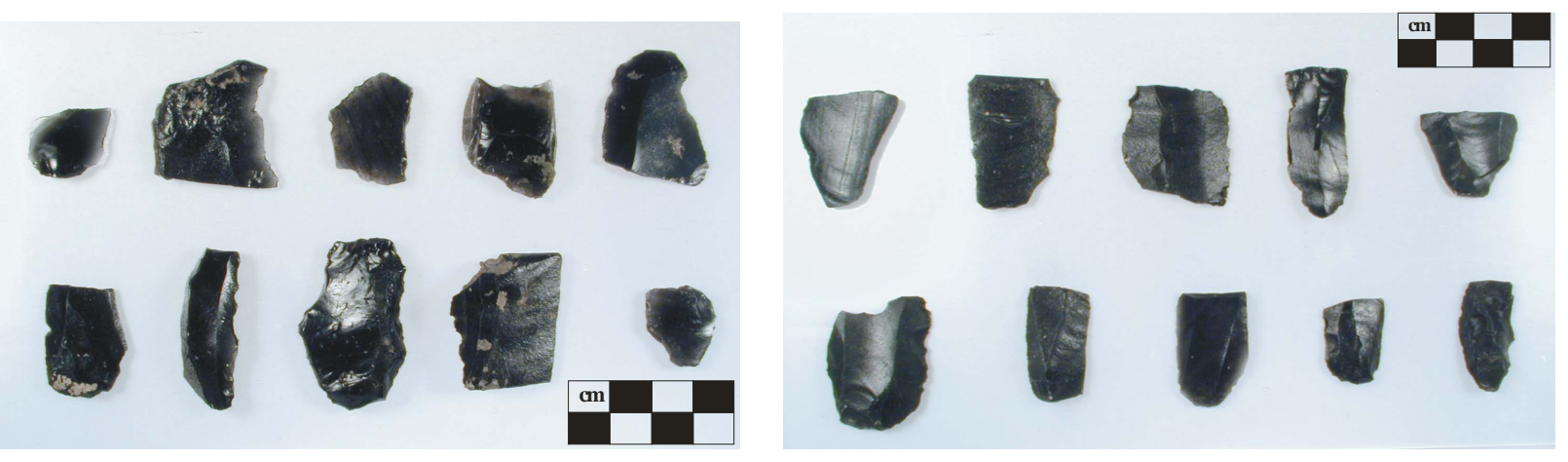

Figure 2. Examples of obsidian artifacts tested, from (a) Su Carroppu (left) and (b) San Gemiliano (right).

\section{METHODS}

It has been widely demonstrated that many different analytical methods have the capability of distinguishing between obsidian subsources, if geological samples from known localities are also analyzed to compare with. The most widely used methods for Mediterranean obsidian have been instrumental neutron activation analysis (INAA), X-ray fluorescence (XRF), the electron microprobe, and more recently, particle induced X-ray emission (PIXE) and laser ablation ICP mass spectrometry (LA-ICP-MS) [11,24-25]. The main issues for archaeologists 
selecting one of these methods have been cost, availability, and whether they are destructive to artifacts. In this study, LA-ICP-MS was specifically selected because of its low per-sample cost and negligible destructive effect.

ICP mass spectrometry was applied to obsidian sourcing in the Mediterranean nearly two decades ago, but the initial laser ablation units and software available at that time were not userfriendly, while producing liquid solutions from volcanic obsidian required the use of potentially harmful acids (e.g. HF) at high temperatures and pressures [26]. So even though the quadrupole ICP-MS system used at the time was successful in distinguishing obsidian subsources and analyzing other archaeological materials [27], other low-cost, minimally destructive analytical methods (mainly the electron microprobe) were used by the first author for his dissertation research [2, 6-7].

Since that time, newer ICP-MS instruments and accessories have been developed, and LA-ICP-MS was chosen for this study as part of a larger central Mediterranean project investigating obsidian subsources on other islands (Lipari, Palmarola, Pantelleria) that would not be differentiable using the electron microprobe, which is limited to detecting major and minor elements. Details on the instrument and methods used for the LA-ICP-MS instrument at the Missouri University Research Reactor follow, while the results obtained for these other island sources as well as archaeological sites in various parts of Italy, have been published elsewhere $[25,28-34]$.

The obsidian samples in this study were analyzed using a Thermo Elemental Axiom high resolution magnetic sector ICP mass spectrometer capable of resolving masses as close as 0.001 atomic mass units apart. The ICP-MS was coupled to a Merchantek Nd-YAG 213-nanometer laser ablation unit, and up to ten samples were mounted in the laser ablation chamber at any one time. The laser was operated at $80 \%$ power $(\sim 1.5 \mathrm{~mJ})$ using a $200 \mathrm{Fm}$ diameter beam, firing at 20 times per second. A rectangular raster pattern of approximately $4 \mathrm{~mm} 2$ was drawn over a relatively flat spot on each sample. The laser scanned across the raster area at $70 \mathrm{Fm}$ per second. The laser beam was allowed to pass over the ablation area one time prior to data acquisition in order to remove possible contaminants from the surface of the sample, and to permit time for sample uptake and for the argon plasma to stabilize after the introduction of fresh material. Analytes of interest were scanned three times and averaged. In most cases, the \%RSD was 5$10 \%$.

Standardization was accomplished by calibrating the instrument with the NIST SRM-610 and SRM-612 glass wafers doped with 61 elements. Two obsidian glasses calibrated in a roundrobin exercise by the International Association of Obsidian Studies were also used. Monitoring the amount of material removed by the laser and transported to the ICP is complicated by several factors making normalization difficult. Conditions such as the texture of the sample, hardness of the sample, location of the sample in the laser chamber, laser energy, and other factors affect the amount of material introduced to the torch. A normalization method described by Gratuze et al. [35] was employed here.

In the current study, about 40 elements were measured using a resolution of 6000 . The high resolution was necessary to reduce the number of ions striking the multiplier caused by several of the high concentration elements (esp. $\mathrm{Na}, \mathrm{Al}, \mathrm{Si}, \mathrm{K}$, and $\mathrm{Fe}$ ). Relative concentrations for all elements were determined by comparing the unknowns to the NIST glass and obsidian standards. To convert the relative concentrations into absolute values, normalization was accomplished converting the relative concentrations to oxides and then normalizing the total to $100 \%$. The method yields satisfactory concentrations for all major and trace elements. 


\section{RESULTS AND DISCUSSION}

The results of the LA-ICP-MS analyses are clearly grouped into the four primary Monte Arci subsources (SA, SB1, SB2, SC) as illustrated in Figure 3. While it is possible to discriminate between SC subsources (SC1, SC2) and SB1 sub-subsources (SB1a, SB1b, SB1c), such distinctions are not significant for this study (see [11]). A simple bi-plot of element ratios $\mathrm{Fe} / \mathrm{Cs}$ vs. $\mathrm{Sm} / \mathrm{Sr}$ is sufficient to separate these subsources, while multivariate statistical analyses provide even clearer distinctions. The numeric results for each of the four sites tested in this study are provided in Table 1.

A comparison by chronological phases of the percentages of the three main subsources (SA, SB, SC) used at all studied sites in southern Sardinia [this study; 15, 19] indicates that there were general changes from the Early to Middle to Late Neolithic time periods, with a big drop in the presence of type SB obsidian, and a major increase in the use of type SC (Figure 4).

When the subsource percentages for Su Carroppu are compared with the data for other Early Neolithic sites in Sardinia (Santa Caterina, Filiestru, Sa Corona) and in Corsica (Strette, Pietracorbara, Lumaca), there are clearly very similar patterns of usage, especially of type SB obsidian [36] (Figure 5). A similar comparison, for the three Late Neolithic sites tested in this study, with others in southern (Barbusa, Tracasi) and northern (Molia, Sa Ucca, Filiestru, Monte d'Accoddi, Contraguda, Li Muri, Liscia Pilastro) Sardinia, and in Corsica (I Calanchi, Basi, Saint Pancrace, Monte Grosso, Strette), again shows similarity in obsidian subsource usage across these major regions (Figure 6). For these Late Neolithic sites it is also clear that type SB obsidian has become of negligible importance, while type SC obsidian dominates most of the assemblages tested.

The presence of obsidian from two or three subsources at each archaeological site tested in this study, with similarity in patterning with sites in northern Sardinia and Corsica, strongly suggests broad geographic similarity both in the purpose of obsidian usage, and in the socioeconomic circumstances in which it occurred. The absence of strong outliers supports a downthe-line model of obsidian trade during the neolithic period, in which the quantity/frequency of obsidian in lithic assemblages decreases with distance from Monte Arci, but with similar representation of the multiple obsidian subsources. The geographically consistent decrease in the use of the SB subsource by the Late Neolithic period is likely to result from the modest geological quantity accessible on the west side of Monte Arci, at a time when increased production and exchange of the greater quantity of accessible SC obsidian is supported by the high levels of primary reduction revealed by survey and excavation in the Sennixeddu area on the east side of Monte Arci [37].

Table 1. Obsidian sourcing results for the archaeological sites tested in this study.

\begin{tabular}{|l|l|c|c|c|c|}
\hline Site & Time Period & No. & SA & SB & SC \\
\hline Su Carroppu (Sirri, Carbonia) & Early Neolithic & 20 & 8 & 5 & 5 \\
\hline S. Gemiliano (Sestu) & Late Neolithic & 22 & 4 & & 17 \\
\hline Cuccuru Ibba (Capoterra) & Late Neolithic & 29 & 16 & & 13 \\
\hline Is Solinas (Carbonia) & Late Neolithic & 24 & 3 & 1 & 20 \\
\hline & Total tested & 95 & 31 & 6 & 55 \\
\hline & & & $33.7 \%$ & $6.5 \%$ & $59.8 \%$ \\
\hline
\end{tabular}




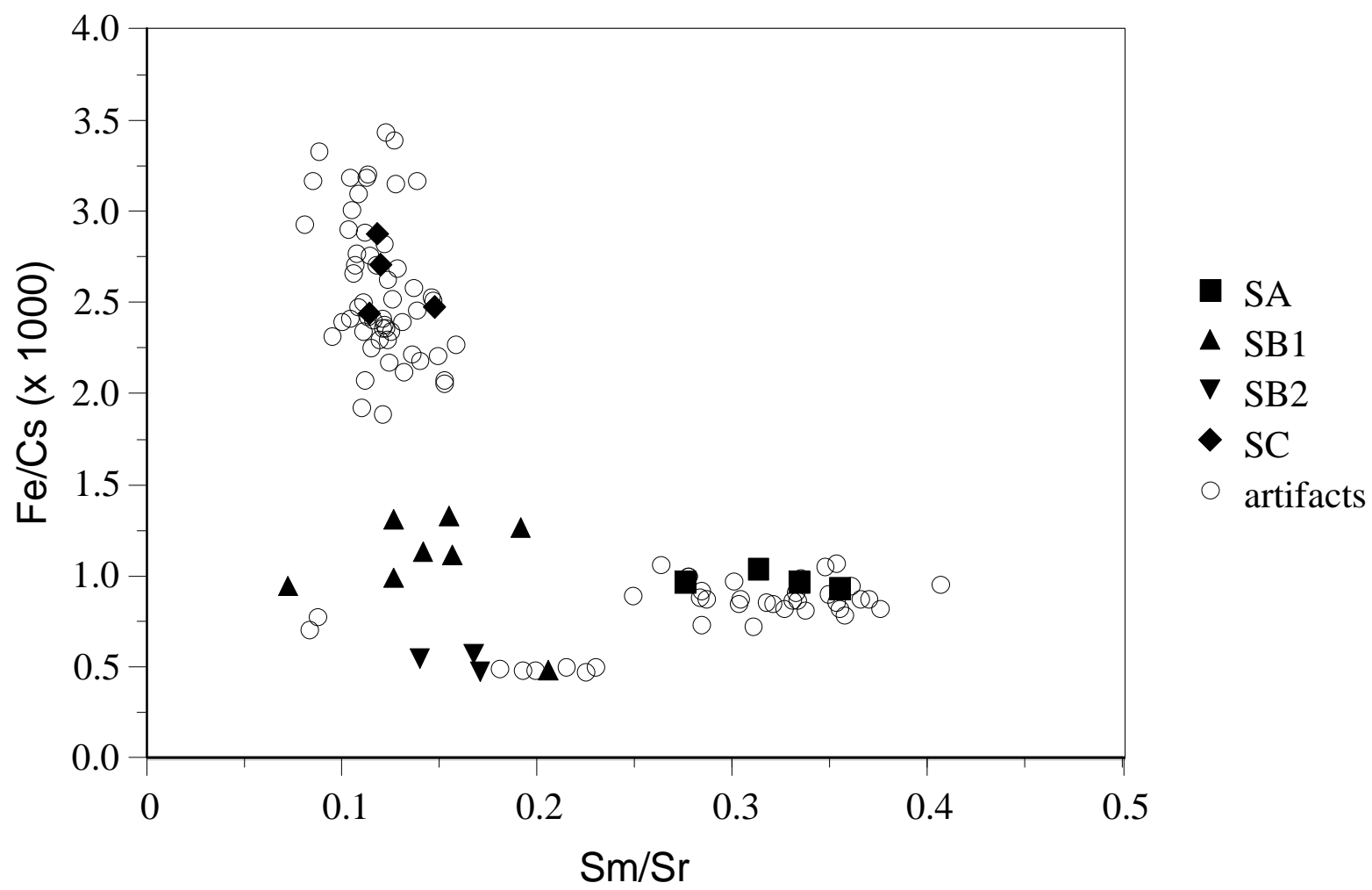

Figure 3. Laser ablation ICP mass spectrometry (LA-ICP-MS) data discriminating Monte Arci subsources (solid symbols) and the archaeological obsidian artifacts tested (open circles).

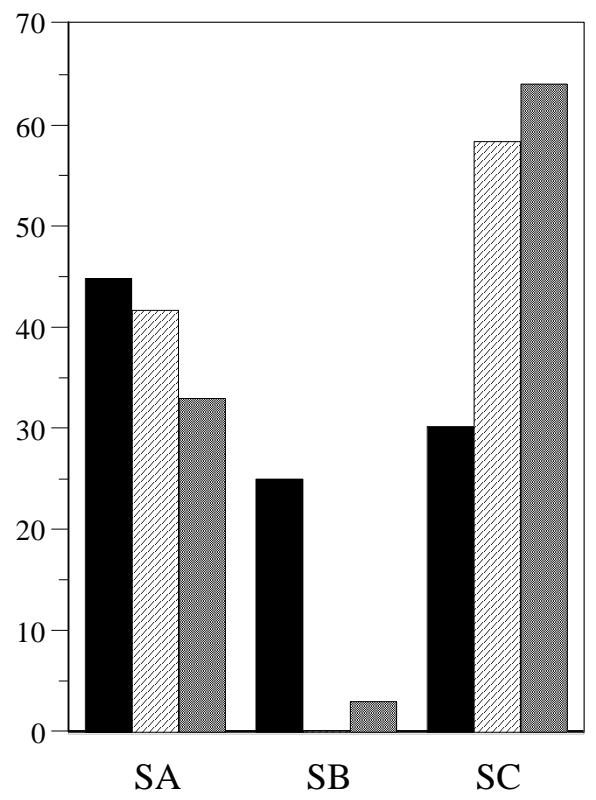

Figure 4. Bar chart of obsidian usage in southern Sardinia during three Neolithic time periods $($ Early Neolithic $=$ blue, Middle Neolithic $=$ green, Late Neolithic $=$ red $)$ 


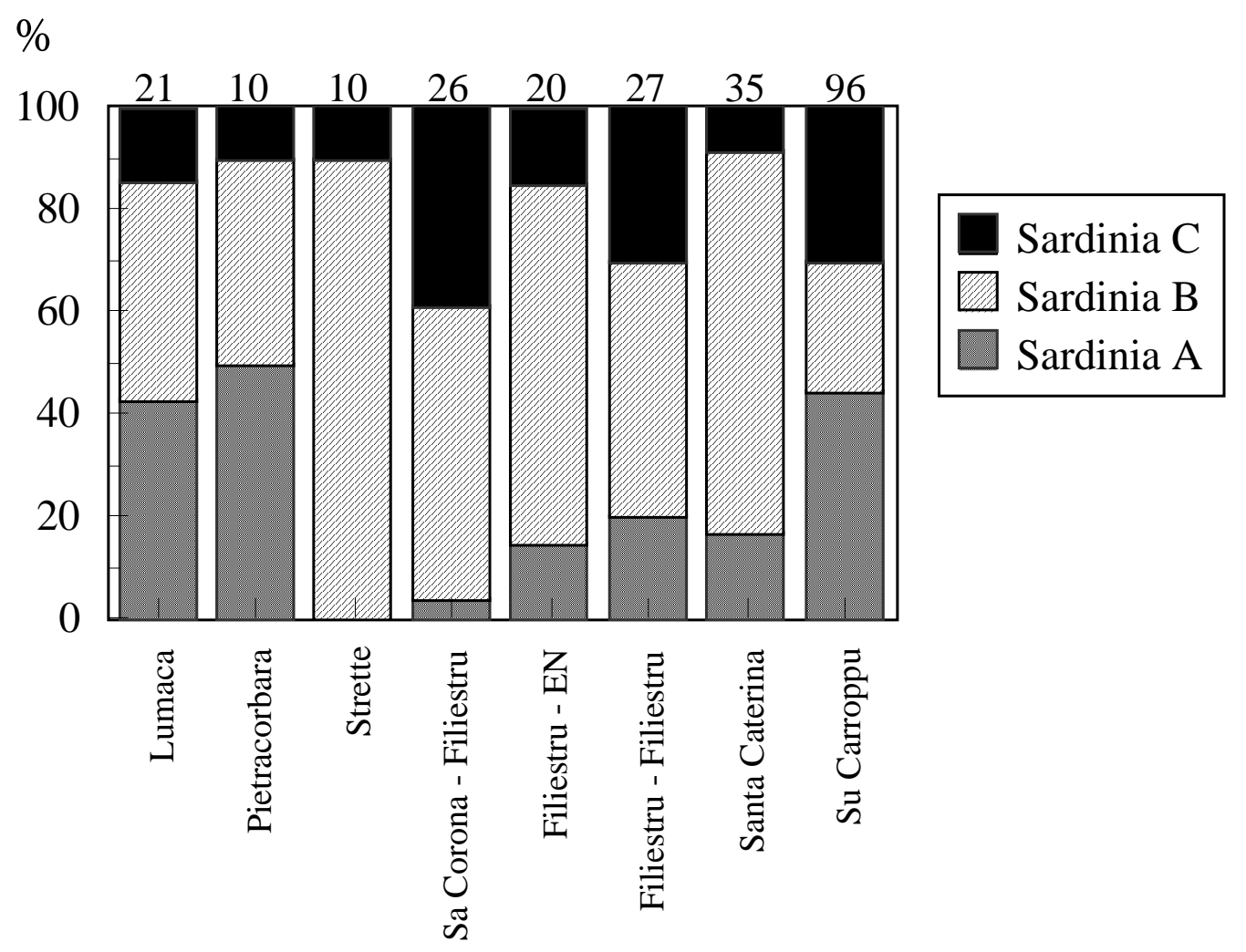

Figure 5. Bar chart of obsidian sources used at Early Neolithic sites in Sardinia and Corsica. Number of samples tested for each site shown at the top.

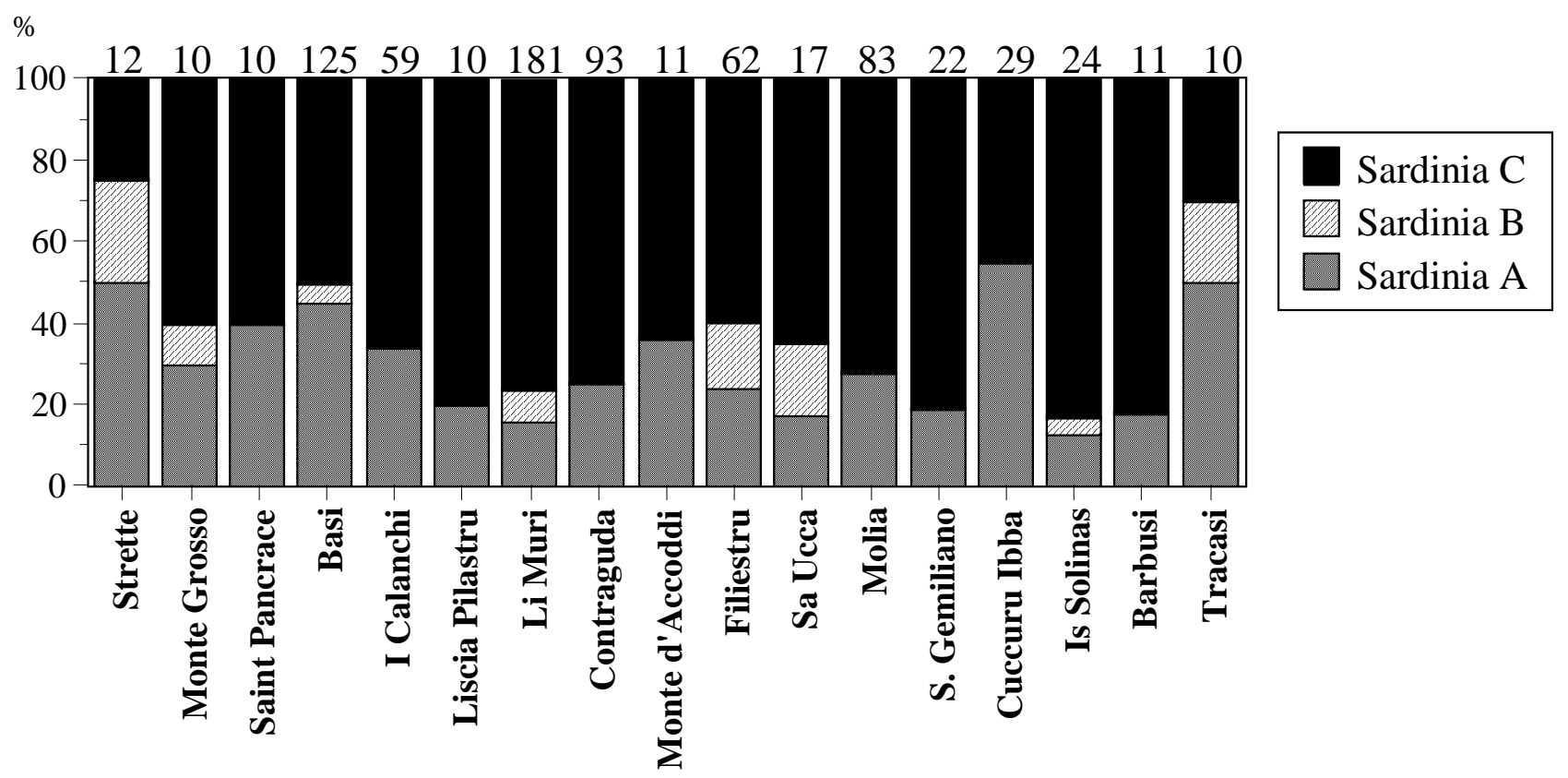

Figure 6. Bar chart of obsidian sources used at Late Neolithic sites in Sardinia and Corsica. Number of samples tested for each site shown at the top. 


\section{CONCLUSION}

The results obtained using virtually non-destructive, LA-ICP-MS analysis of 95 selected obsidian artifacts from four neolithic period sites in southern Sardinia parallel the patterns of usage of Monte Arci subsources found for sites in northern Sardinia and in Corsica. These patterns of exploitation support a down-the-line model of obsidian trade during the neolithic period, but with chronological changes that are best explained by increased socioeconomic complexity. Further analyses and integration of sourcing data with lithic typology [19], usewear studies [38], and investigation and excavation of source localities and production workshops [12, 39] will lead to better understanding of the role of obsidian in the prehistoric Mediterranean.

\section{ACKNOWLEDGMENTS}

The research presented here was supported by a grant to the first author from the National Science Foundation (BCS-0075535).

\section{REFERENCES}

1. C. Puxeddu, Studi Sardi 14-15, 10-66 (1958).

2. R.H. Tykot, Prehistoric Trade in the Western Mediterranean: The Sources and Distribution of Sardinian Obsidian (PhD dissertation, Harvard University, 1995).

3. B.R. Hallam, S.E. Warren, C. Renfrew, Proc. Prehistoric Society 42, 85-110 (1976).

4. M.P. Mackey and S. E. Warren, Proceedings of the 22nd Symposium on Archaeometry (1982) pp. 420-431.

5. R.H. Tykot, in Sardinia in the Mediterranean: A Footprint in the Sea, edited by R.H. Tykot and T.K. Andrews (Sheffield Academic Press, Sheffield, 1992) pp. 57-70.

6. R.H. Tykot, J. Mediterranean Archaeology 9, 39-82 (1996).

7. R.H. Tykot, J. Archaeological Science 24, 467-479 (1997).

8. R.H. Tykot, in Archaeological Obsidian Studies: Method and Theory, edited by M.S. Shackley (Plenum, New York, 1998) pp. 67-82.

9. R.H. Tykot and A.J. Ammerman, Antiquity 274, 1000-1006 (1997).

10. R.H. Tykot, in Social Dynamics of the Prehistoric Central Mediterranean, edited by R.H. Tykot, J. Morter, J.E. Robb (Accordia Research Institute, London, 1999) pp. 67-82.

11. R.H. Tykot, Accounts of Chemical Research 35, 618-627 (2002).

12. C. Luglie, F.-X. Le Bourdonnec, G. Poupeau, M. Bohn, S. Meloni, M. Oddone and G. Tanda, C.R. Palevol 5, 995-1003 (2006).

13. R.H. Tykot, Materials Research Society Proceedings 712, 143-157 (2002).

14. R.H. Tykot, Sources and Trade of Obsidian in Corsica (France), Materials Research Society, Boston, Massachusetts, Nov. 29-Dec. 3 (2004).

15. J.W. Michels, E. Atzeni, I.S.T. Tsong, G.A. Smith, in Studies in Sardinian Archaeology, edited by M.S. Balmuth and R.J. Rowland, Jr. (University of Michigan Press, Ann Arbor, 1984) pp. 83-114.

16. E. Atzeni, Rivista di Scienze Preistoriche XXVII, 478-479 (1972).

17. E. Atzeni, Rivista di Scienze Preistoriche XXXII, 357-358 (1978).

18. E. Atzeni, C. Lugliè, M.V.G. Migaleddu, in L'ossidiana del Monte Arci nel Mediterraneo, La ricerca archeologica e la salvaguardia del paesaggio per lo sviluppo delle zone interne della Sardegna, Atti del $2^{\circ}$ Convegno Internazionale, Pau, 28-30 novembre 2003 (Cagliari, 2004) pp. 185-200. 
19. C. Lugliè, C., F.-X. Le Bourdonnec, G. Poupeau, E. Atzeni, S. Dubernet, P. Moretto, L. Serani, J. Archaeological Science 34, 428-439 (2007).

20. E. Atzeni, La preistoria del Sulcis Iglesiente (Viale Elmas, Cagliari, 1987).

21. E. Atzeni, Cagliari preistorica (ETS Editrice, Pisa, 1986).

22. E. Atzeni, Cagliari Preistorica (University Press Archeologia, Cagliari, 2003).

23. E. Atzeni, Studi Sardi XVII, 5-93 (1962).

24. R.H. Tykot, in Physics Methods in Archaeometry. Proceedings of the International School of Physics "Enrico Fermi”, edited by M. Martini, M. Milazzo and M. Piacentini (Società Italiana di Fisica, Bologna, 2004) pp. 407-432.

25. R.H. Tykot, in Acts of the XIVth UISPP Congress, University of Liège, Belgium, 2-8 September 2001. Section 9: The Neolithic in the Near East and Europe. BAR International Series 1303:25-35 (Archaeopress, Oxford, 2004).

26. R.H. Tykot, International Association for Obsidian Studies Newsletter 5, 9 (1991).

27. R.H. Tykot and S.M.M. Young, Archaeological Chemistry Symposium Series 625, 116-130 (1996).

28. L. Lai, R.H. Tykot and C. Tozzi, in Atti del XXXIX Riunione Scientifica dell'Istituto Italiano di Preistoria e Protostoria: Materie prime e scambi nella preistoria italiana, Firenze, 25-27 November 2004 (Firenze, 2006) pp. 598-602.

29. R.H. Tykot, in L'ossidiana del Monte Arci nel Mediterraneo: recupero dei valori di un territorio, a cura di P. Castelli, B. Cauli, F. Di Gregorio, C. Lugliè, G. Tanda and C. Usai (Tipografia Ghilarzese, Ghilarza, 2004) pp. 118-132.

30. R.H. Tykot, in Préhistoire et protohistoire de l'aire tyrrhénienne/Preistoria e protostoria dell'area tirrenica, a cura di C. Tozzi and M.C. Weiss (Felici Editori, 2007) pp. 217-220.

31. R.H. Tykot, B.A. Vargo, C. Tozzi and A. Ammerman, in Atti del XXXV Riunione Scientifica, Le Comunità della Preistoria Italiana. Studi e Ricerche sul Neolitico e le Età dei Metalli (Istituto Italiano di Preistoria e Protostoria, Firenze, 2003) pp. 1009-1112.

32. R.H. Tykot, A.J. Ammerman, M. Bernabò Brea, M.D. Glascock and R.J. Speakman, Geoarchaeological and Bioarchaeological Studies 3, 103-106 (2005).

33. R.H. Tykot, T. Setzer, M.D. Glascock and R.J. Speakman, Geoarchaeological and Bioarchaeological Studies 3, 107-111 (2005).

34. R.J. Speakman, M.D. Glascock, R.H. Tykot, C. Descantes, J.J. Thatcher, C.E. Skinner, K.M. Lienhop, in ACS Symposium Series 968, 275-296 (2007).

35. B. Gratuze, M. Blet-Lemarqu and J.-N. Barrandon, Journal of Radioanalytical and Nuclear Chemistry 247, 645-565 (2001).

36. R.H. Tykot, American Chemical Society Symposium Series 831, 169-184 (2002).

37. R.H. Tykot, C. Lugliè, T. Setzer, G. Tanda and R.W. Webb, International Association of Obsidian Studies Bulletin 35, 9 (2006).

38. T. Setzer, R.H. Tykot and C. Tozzi, International Association for Obsidian Studies Bulletin 31, 8 (2004).

39. R.H. Tykot, M.R. Iovino, M.C. Martinelli and L. Beyer, in Atti del XXXIX Riunione Scientifica dell'Istituto Italiano di Preistoria e Protostoria: Materie prime e scambi nella preistoria italiana, Firenze, 25-27 November 2004 ((Istituto Italiano di Preistoria e Protostoria, Firenze, 2006) pp. 592-597. 